\title{
Parotid Abscess Treated with Percutaneous Drainage
}

\author{
So Young Choi ${ }^{1}$, Ji Dae Kim¹, Wang Woon Cha ${ }^{2}$, Ho Yun Lee ${ }^{2}$, \\ Dong Sik Chang ${ }^{2}$, Ah-Young Kim², and Myoung Su Choi ${ }^{2}$ \\ ${ }^{I}$ Departments of Radiology, ${ }^{2}$ Otolaryngology-Head and Neck Surgery, College of Medicine, Eulji University, Daejeon, Korea
}

\author{
경피적 배농술로 치료한 이하선 농양 \\ 최소영 ${ }^{1} \cdot$ 김지대 $^{1} \cdot$ 차왕운 $^{2} \cdot$ 이호윤 $^{2} \cdot$ 장동식 $^{2} \cdot$ 김아영 $^{2} \cdot$ 최명수 $^{2}$ \\ 을지대학교 의과대학 영상의학과학교실, ${ }^{1}$ 이비인후과학교실 ${ }^{2}$
}

\author{
Received May 20,2016 \\ Revised June 30,2016 \\ Accepted July 7, 2016 \\ Address for correspondence \\ Myoung Su Choi, MD \\ Department of Otolaryngology- \\ Head and Neck Surgery, \\ College of Medicine, \\ Eulji University, \\ 95 Dunsanseo-ro, Seo-gu, \\ Daejeon 35233, Korea \\ Tel $+82-42-611-3129$ \\ Fax $+82-42-611-3136$ \\ E-mail mschoi@eulji.ac.kr
}

Background and Objectives The parotid abscess is a rare disease. It occurs mainly in patients with poor oral hygiene, dehydration, and immune compromised. This study aims to analyze clinical presentations of the parotid abscess treated with ultrasonography and fluoroscopy guided percutaneous drainage.

Subjects and Method A retrospective review of medical records were carried out for nine patients with parotid abscess treated with percutaneous drainage during the period from March 2007 to May 2013.

Results Of the nine patients identified with parotid abscess, there were seven males and two females who were in the age range of 41 to 85 years (mean age of 61.8). The mean level of the serum amylase was $167.4 \mathrm{IU} / \mathrm{L}$ (ranging from 52 to 343). Of the nine patients, two were found with intra-parotid cystic tumor, one was infected with the Tuberculosis, and six were found with an unidentifed parenchymal infection. All except one patient were improved after percutaneous drainage. One patient, who suffered underlying diabetes, chronic renal failure and liver cirrhosis, died due to sepsis that rapidly progressed from parotid abscess despite percutaneous drainage. The mean period of hospitalization was 16.1 days. Bacteria isolations resulted in identification for 4 patients $(44.4 \%)$.

Conclusion Parotid abscess could be successfully treated with ultrasonography and fluoroscopy guided percutaneous drainage unless it involved multiple regions or progressing rapidly.

Korean J Otorhinolaryngol-Head Neck Surg 2016;59(9):655-60

Key Words Abscess · Catheters · Drainage · Parotid gland · Ultrasonography.

\section{서 론}

이하선 농양은 급성 화농성 이하선염의 합병증으로 발생 하며 매우 드물게 보고되는 질환이다. ${ }^{1)}$ 초기의 급성 화농성 이하선 염증은 항생제 치료에 호전되는 경우가 많지만, 일단 농양이 발생한 경우에는 외과적 배농이 필요한 경우가 많다. 구강위생이 불량하거나 탈수가 심한 경우, 면역억제상태 등이 이하선 농양의 위험인자로 알려져 있다. ${ }^{2)}$

과거에는 이하선 농양의 외과적 배농은 이하선 절제술과 똑같은 절개방법으로 피판을 박리한 후 이하선을 싸고 있는
근막부위에 안면신경의 주행과 평행하게 절개를 가하는 것 으로 알려져 있다. ${ }^{3)}$ 그러나, 수술적 위험도가 높고, 안면신경 에 손상을 줄 위험성이 높으며, 수술 후 창상 감염과 회복 시 간이 더딘 단점이 있다. ${ }^{2)}$

최근에는 초음파를 이용하여 피부에 절개 없이 농양부위를 직접 확인하면서 굵은 주사기로 흡입하거나, 카테타를 삽입하 여 배농하는 방법이 두경부 영역 여러 분야에서 널리 이용되어 왔다. ${ }^{4-7)}$ 저자들도 초음파와 투시장비를 이용하여 외과적 수 술 없이 이하선 농양을 치료한 경험을 하였기에, 이하선 농양 의 임상적 특징과 더불어 치료경험에 관하여 논의하고자 한다. 


\section{대상 및 방법}

2007년 3월부터 2013년 5월까지 본원에서 이하선 농양으로 진단받아 치료받은 9 명의 환자의 의무기록을 후향적으로 분 석하였다. 이하선 농양은 환자의 임상적 양상과 더불어 영상 의학적 검사인, $\mathrm{CT}$ 나 초음파를 통해서 진단되었으며, 배농 시 에 육안적으로 고름이 나온 것만을 이하선 농양으로 정의하 였다. 초음파를 먼저 시행한 경우에는, 소아 환자인 경우, 당뇨 병으로 metformin을 복용하는 자, 신부전이 있으면서 당일 투석이 어려운 자에게 시행하였다. 이하선 환자들은 술 전 48 시간 이상 정맥을 통해 경험적 항생제(amoxicillin/clavulanic acid, metronidazole)를 항생제 감수성 결과가 나오기 전까 지 사용하였으며, 약물치료에 반응을 보이지 않은 경우에는 영상의학과에 의뢰하여 초음파와 투시를 이용한 경피적 배 농술을 시행하였다. 시술 후 배액이 2일 연속으로 $1 \mathrm{cc}$ 이상 나오지 않은 경우, 초음파 검사를 다시 시행하여 농양의 크 기를 재확인한 후, 완전 배액된 경우에는 카테터를 제거하고,
일부 남은 경우에는 초음파를 보면서 카테타의 위치를 재위 치 시키거나, 굵은 바늘로 흡인하여 치료하였다. 퇴원 후 3개 월 이상 외래 추적관찰을 한 환자를 대상으로 하였다. 환자 의 나이, 성별, 기저질환, 재원기간, 배양검사결과, 이하선 부위 의 침범부위 등을 분석하였다. 본 연구는 기관윤리심의위원 회로부터 승인을 받아 진행하였다(EMC-2013-07-009).

\section{초음파와 투시를 이용한 경피적 배농술 절차}

9명 모두 영상의학과 중재적 시술실에서 배농을 시행하였 다. 환자는 앙와위 자세로 있으며, 이하선 부위는 베타딘과 알코올로 소독하였다. $1 \%$ 리도카인으로 카테타를 삽입할 피 부에 침윤 주사하여 피부를 마취시켰다. 5 18 MHz linear 프로브를 갖는 초음파(Noblus; Hitachi-Aloka, Tokyo, Japan) 로 농양의 위치를 보면서 21-gauge, $150 \mathrm{~mm}$ Chiba-needle (Top, Tokyo, Japan)을 농양 내부에 위치시키고, 이 부위에 조 영제를 투여하여서 실질적인 농양의 크기를 투시장비(Axion Artis FA, Siemens, Erlangen, Germany)를 통하여 확인하면
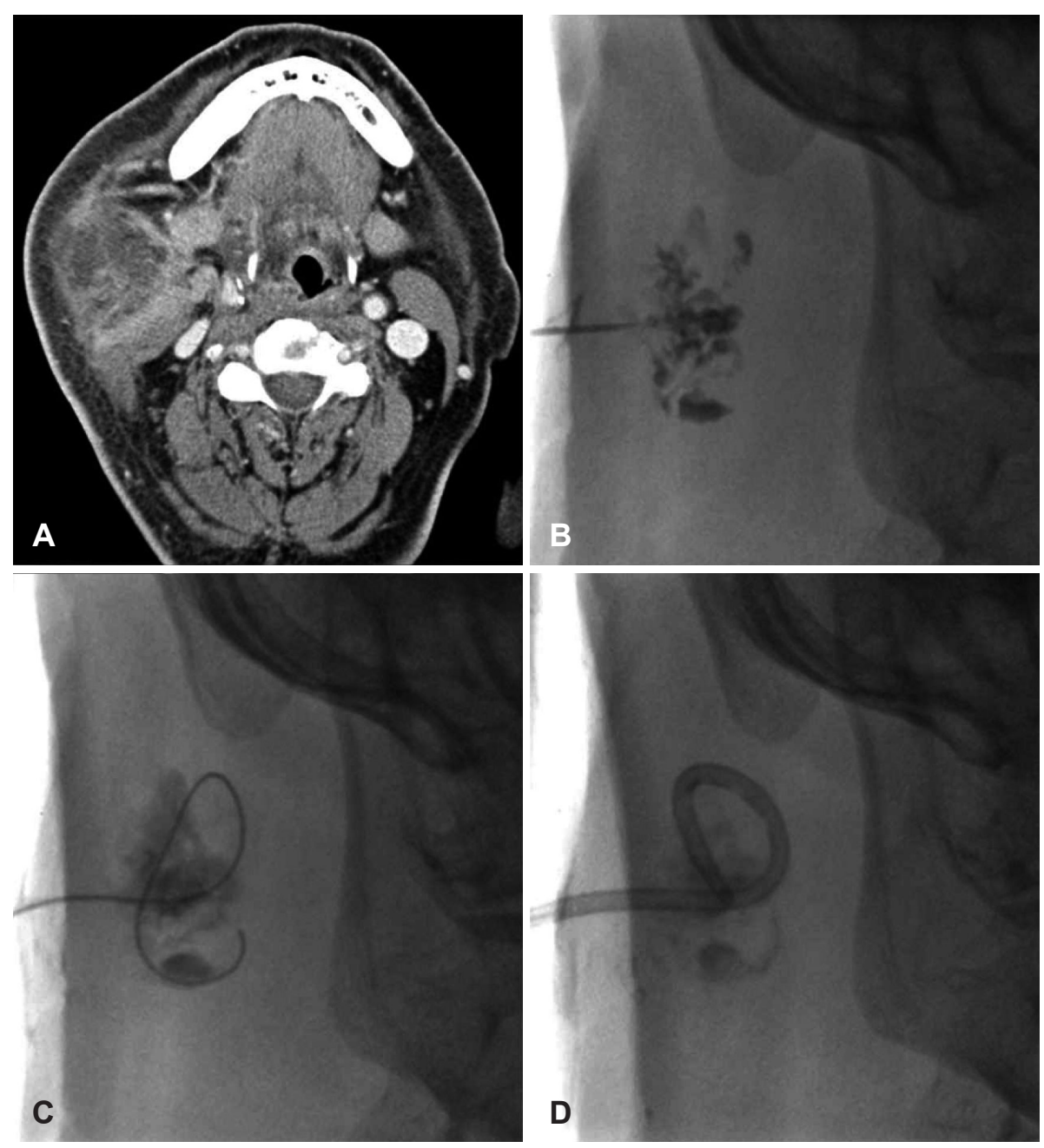

Fig. 1. Procedure of the percutaneous drainage. Axial contrast enhanced CT image shows enlarged right parotid gland with internal low attenuation and peripheral enhancement (A). Contrast media disperses into the parotid abscess, ensuring the position of the needle (B). A guide wire is inserted into the abscess $(C)$ to assist pigtail catheter placement under fluoroscopy guidance (D). 
서, 농양의 크기에 맞게 6 8.5 프렌치(French, F) pigtail 카테 터(William Cook Europe, Bjaeverskov, Denmark)를 농양 내부에 거치한 후, 카테터는 피부에 나일론 봉합사를 이용하 여 고정하였다(Fig. 1). 카테터를 통해 나온 고름은 균배양검 사를 시행하였다.

\section{결 과}

9명의 환자가 이하선 농양의 진단에 부합하였으며, 남자가 7명, 여자가 2명이었으며, 평균나이는 61.8세(41 85세)였다 (Table 1), 혈액 아밀라아제 수치는 평균 167.4 IU/L(52 343 $\mathrm{IU} / \mathrm{L}$ )로 정상수치보다 높게 측정되었으나, 정상 수치 이하인 경우도 3 명의 환자에서 관찰되었다. 정상 수치 이하인 경우 는, 결핵성 농양환자 1 명, 이하선내 낭성 종양이 감염된 경우 가 2 명이었다. 농양이 양측에 발생한 경우는 없었으며, 우측에 5 명, 좌측에 4명이 발생하였다. 혈액 백혈구 수치는(white blood cell) 평균 $13.6610^{9} / \mathrm{L}$ 으로 증가하였으며, 2명에서는 정상범위 내에 있었다(Table 1). C 반응성 단백질(C-reactive protein)은 평균 $8.89 \mathrm{mg} / \mathrm{L}$ 로 증가하였으며, 9명 환자 모두 에서 정상범위보다 증가하였다(Table 1).

농양이 이하선에 발생한 부위로는 천엽이 4명, 심엽이 2명, 천엽과 심엽 모두에 발생한 경우가 3 명이었다. 1 명의 환자에 서(9번 환자) 이하선 농양과 더불어 동측 저작근 공간에도 농양이 발생하였다. 농양의 크기는, CT나 초음파 상에서, 제 일 큰 직경을 기준으로 평균 $35.2 \mathrm{~mm}(20 \sim 59 \mathrm{~mm})$ 로 확인되 었으며, $8.5 \mathrm{~F}$ 카테타를 이용한 경우가 5명으로 가장 많았으 며, 나머지 4명은 6 6.5 F를 사용하였다. 재원기간은 6일에서 33 일까지로(평균 16.1 일) 다양하게 분포하였다. 환자가 가지
고 있는 기저질환은 당뇨가 3명으로 제일 많았으며, 암을 진 단받아 치료받은 병력이 2 명에서 있었다. 9 명의 이하선 농양 환자 중에서 9 번 환자를 제외하고는 모두 합병증 없이 완치 되었다. 9번 환자는 당뇨, 간경화, 만성 췌장염, 간암과 대장 암 병력, 만성 신부전으로 투석을 시행받고 있는 자로서, 이하 선 농양으로 진단받아 경피적 배농술 시행받은 지 11일 만에 패혈증으로 진행하여 사망하였다.

배양검사상 9명 중, 4명에서 균배양이 되었다(44.4\%). 2명의 환자에서 Staphylococcus aureus(S. aureus)가 배양되었으며, Streptococcus anginosus도 1명에서 확인되었다. 3번 환자에 서 Mycobacterium Tuberculosis가 배양되었고 중합효소연 쇄반응(Polymerase chain reaction, PCR) 검사에서도 결핵 균이 확인되었다. 이후, 흥부 X선 검사에서도 활동성 폐결핵 이 발견되어, 내과로 전과하여 결핵치료를 병행하였다.

9 명의 환자에서 대부분 1 회의 경피적 배농만으로 완전 배 농이 되었으나, 2 번 환자에서는 카테타 삽입 이후에도 농양 이 남아 있는 부위가 확인되어 추가적으로 18 게이지 주사침 으로 흡인을 2 번 시행하여 완치하였다. 9 번 환자에서는 초기 에 이하선과 저작근 공간에 각각 농양이 확인되어, 각각의 부위에 한 개씩 총 2 개의 카테타를 삽입하였다. 5 번 환자에 서는 초음파를 보면서 카테타를 새로 위치시켜 보았으나 호 전이 없어, 기존의 카데타를 제거하고, 새로운 카테타를 사용 하여 배농 후 호전되었다.

\section{고 찰}

이하선 농양은 주로 구강협부의 이하선관(Stensen's duct) 을 통한 바이러스나 세균의 상행성 감염으로 발생한다. ${ }^{1)}$ 이

Table 1. Demographic charateristics of patients with parotid abscess

\begin{tabular}{|c|c|c|c|c|c|c|c|c|c|c|c|c|c|}
\hline$N$ & Sex & Age & Side & $\begin{array}{l}\text { Catheter } \\
\text { (F) }\end{array}$ & $\begin{array}{l}\text { Amylase } \\
\text { (IU/L) }\end{array}$ & $\begin{array}{l}\text { WBC } \\
(109 / \mathrm{L})\end{array}$ & $\begin{array}{l}\text { CRP } \\
(\mathrm{mg} / \mathrm{L})\end{array}$ & $\begin{array}{l}\text { Involved } \\
\text { area }\end{array}$ & $\begin{array}{l}\text { Parotid } \\
\text { tumor }\end{array}$ & $\begin{array}{l}\text { Hosp. } \\
\text { day }\end{array}$ & $\begin{array}{c}\text { Catheter } \\
\text { day }\end{array}$ & Culture & Co-morbidity \\
\hline 1 & $M$ & 73 & $R$ & 8.5 & 254 & 8.14 & 11.21 & Supf & & 11 & 9 & CNS & COPD \\
\hline 2 & M & 74 & $R$ & 8.5 & 267 & 23.37 & 30.28 & Whole & & 33 & 31 & & $\begin{array}{l}\text { DM, } \\
\text { gastric ca. }\end{array}$ \\
\hline 3 & M & 41 & L & 8.5 & 60 & 14.18 & 12.42 & Whole & & 13 & 12 & Tuberculosis & Pul Tbc \\
\hline 4 & $\mathrm{~F}$ & 59 & $\mathrm{~L}$ & 8.5 & 52 & 21.73 & 3.39 & Deep & + & 20 & 18 & & RA \\
\hline 5 & $\mathrm{~F}$ & 53 & L & 6 & 343 & 13.75 & 2.5 & Supf & & 28 & 26 & S. anginosus & \\
\hline 6 & M & 74 & $R$ & 6 & 156 & 14.25 & 2.34 & Supf & & 6 & 5 & S. aureus & DM \\
\hline 7 & M & 85 & $R$ & 8.5 & 76 & 8.2 & 4.05 & Deep & + & 12 & 10 & & \\
\hline 8 & M & 54 & L & 6 & 187 & 7.96 & 1.68 & Supf & & 11 & 9 & & \\
\hline 9 & $M$ & 82 & $R$ & 6.5 & 112 & 11.42 & 12.13 & $\begin{array}{l}\text { Whole, } \\
\text { M-space }\end{array}$ & & 11 & 8 & & $\begin{array}{l}\text { DM, CKD, } \\
\text { LC, HCC, } \\
\text { colon ca. }\end{array}$ \\
\hline
\end{tabular}

N: number, R: right, L: left, F: French, WBC: white blood cell, CRP: C-reactive protein, Supf: superficial, M-space: masticator space, Hosp.: hospitalization, CNS: coagulase negative staphylococcus, COPD: chronic obstructive pulmonary disease, DM: diabetes mellitus, ca.: cancer, Pul Tbc: pulmonary tuberculosis, RA: rheumatoid arthritis, CKD: chronic kidney disease, LC: liver cirrhosis, HCC: hepatocellular cancer 
하선 내의 분비선 실질부위의 감염이나, 이하선 내부의 림프 절의 감염을 일으킨 후, 이후 화농성으로 진행하여 발생할 수 있다. ${ }^{1)}$ 이하선 농양을 잘 일으킬 수 있는 선행조건으로는 구 강위생이 불량한 경우, 탈수, 치아관련 감염증, 구강건조, 이 하선관의 결석 등으로의 폐색, 쇼그렌 증후군이나 당뇨병, 이 하선 와르틴 종양(Warthins tumor), 면역저하상태로 알려져 있다. ${ }^{2}$ 우리의 연구에서도 3 명의 환자에서 당뇨를 않고 있었 으며, 암을 진단받은 환자도 2 명에서 있었다. 환자의 평균 연 령이 61.8세로 고령에 속하는 편이었다. 7번 환자의 경우에 는, 이하선 농양으로 진단받기 이전에, 이하선 종양으로 이미 진단을 받았다. 환자가 수술을 원하지 않아서 외래 경과 관찰 중에, 갑작스럽게 종창이 커지게 되어 내원한 경우이다(Fig. 2). 환자는 경피적 배농을 통해 호전된 후, 퇴원 후 6개월 후 에 이하선 천엽절제술을 시행받았으며, 병리학적으로 와르틴 종양으로 최종 진단되었다. 4번 환자의 경우에도 이하선 심 부에 생긴 농양으로, 모양이 이하선 실질에서 생긴 농양과는 다르게, 비교적 경계가 잘 이루어져 있어 와르틴 종양이나 제 1 형 아가미틈새낭 같은 감염성 낭성 종물이 의심되어 퇴원 후 수술을 권유하였으나 환자가 거부하여 경과만 관찰하고 있 는 중이다.

이하선 농양을 일으키는 흔한 균주로는 S. aureus로 알려 져 있으며, 반복적인 이하선염을 일으키는 균주로는 Streptococcus species 이다. 이외에도, Hemophilus influenza, Pseudomonas, Mycobacterium tuberculosis 등도 일으킬 수 있 다고 알려져 있다. ${ }^{8)}$ 본 연구에서는 9명 중에서 4 명에서만 균 주가 동정되었으며, 배양된 균주 중에선 S. aureus가 2명으로 가장 많았다. 균동정률이 떨어지는 것은 균검사 이전에 항생 제 사용과 혐기성균주의 동정이 이루어 지지 않아서 동정이
떨어진 것으로 보인다. 이하선에서 결핵은 드물게 보고되고 있으며, ${ }^{9)}$ 서서히 커지고 주변과 단단하게 붙어 있어 마치, 종 양과 같은 임상양상을 보일 수 있다(Fig. 2B). 따라서 결핵성 농양이 의심될 경우에는, 흡인, 배농 이외에도 결핵균 $\mathrm{PCR}$ 이 나, 조직생검이 필요하다.

이하선 농양의 합병증으로는 드물지만, 안면신경 마비가 보고되고 있다. 본 연구애서는 안면마비는 한 명도 발생하지 않았다. 국내에서도 2014년도에 Lee 등히이 보고하였고, 국외 에서도 드물게 보고가 있다. ${ }^{10,11)}$ 안면신경 마비의 기전으로는, 신경초(nerve sheath)를 통한 염증물질의 화학적 독성이나, 농양이 커지면서 신경을 압박하여 발생하였을 것으로 추정 하고 있다. ${ }^{11}$

급성 이하선 염증은 이하선 농양과 감별하기가 쉽지 않다. 두 경우 모두 수일 이내의 이하선 부위의 종창과 이하선부위 피부의 발적과 동통, 열을 동반할 수 있다. 파동(fluctuation) 이 있으면 이하선 농양으로 진단이 용이하나, 이하선을 싸고 있는 근막이 상당이 두껍기 때문에 촉진 시에 잘 구별이 안 되 는 경우가 많다(Fig. 3). 우리의 연구에서도 모두 CT나 초음파 같은 이미지 검사를 한 후에 알게 된 경우가 대부분이다. 이 하선 실질부위에 발생한 농양은 초기에는 다발성으로 국소 적으로 발생하였다가, 점차 하나로 합쳐지게 되어 커다란 농 양을 형성하게 되며(Fig. 1A), 와르틴 종양처럼 이하선 내의 낭성 종양이 감염된 경우는 비교적 경계가 분명한 농양을 보 이게 된다(Fig. 2A). 이하선에 생길 수 있는 낭성 종양으로는 와르틴 종양이 제일 흔하지만, 양성 혼합 낭종(benign mixed tumor), 점액표피양 암종(mucoepidermoid carcinoma), 선 방상 암종(acinic cell carcinoma) 등도 낭성 변화를 보일 수 있다고 보고되어 있다. ${ }^{12)}$ 또한, 발생학적으로 제 1 형 아가미틈
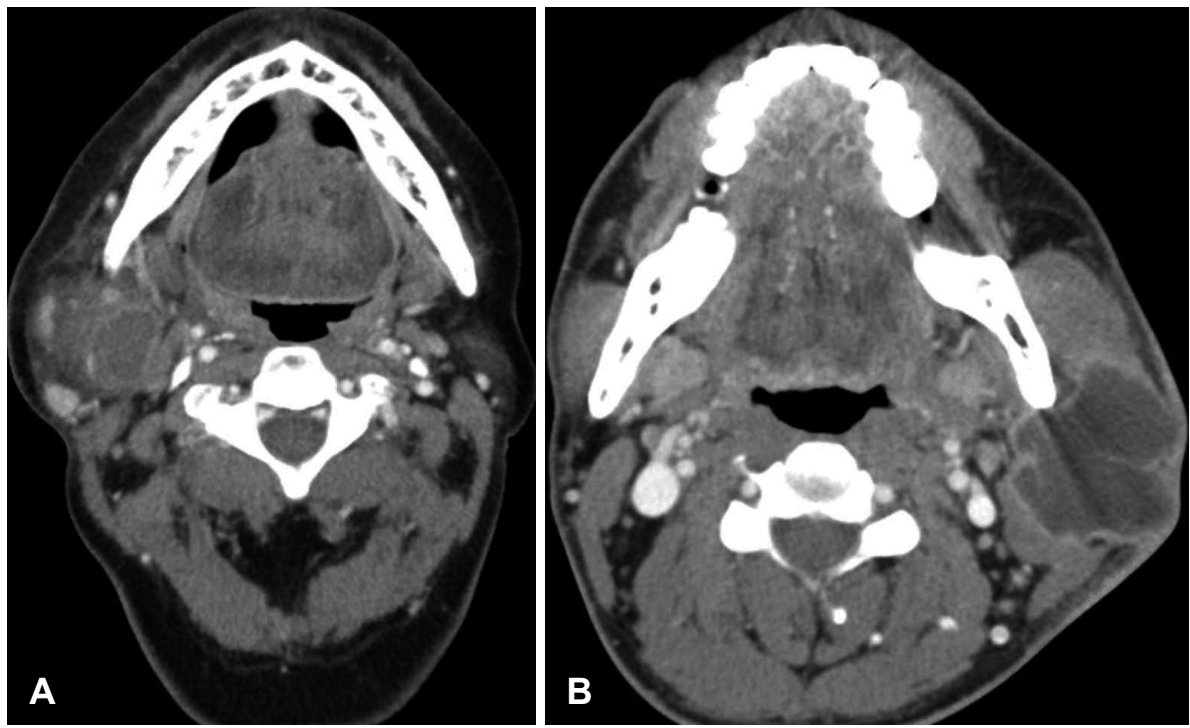

Fig. 2. Axial contrast enhanced CT image shows a relatively well-circumscribed, cystic lesion within the right parotid gland (Parotid tumor) with adjacent soft tissue infiltration (A), CT image shows an irregular shaped, well-circumscribed, cystic lesion with peripheral rim enhancement (Tuberculosis) with adjacent skin thickening (B). 

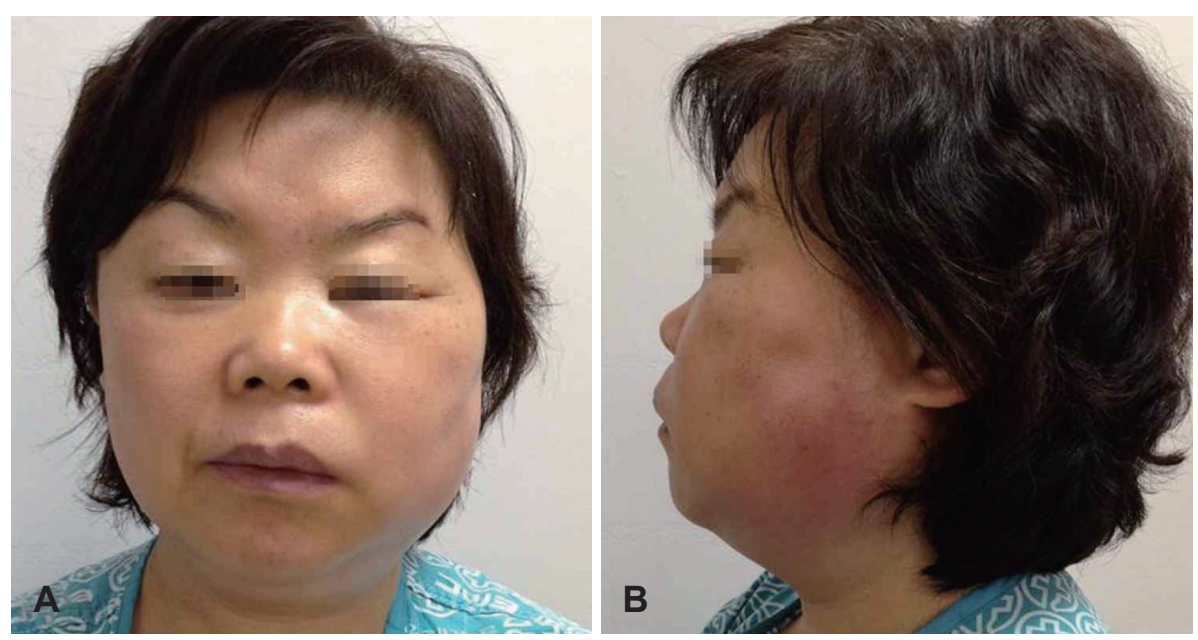

Fig. 3. Photographs of a patient with left-side parotid abscess prior to treatment. Frontal view $(A)$ and lateral view (B).

새낭도 이하선 내부에 발생할 수 있다.

$\mathrm{CT}$ 나 초음파가 주로 진단에 이용되는데, 진단 시 농양 이 외에도 이하선관을 주의깊게 살펴야 한다. 이하선관의 결석 은 방사선투과성인(radiolucent) 경우가 많아서 눈에 잘 띄지 않기 때문에 관이 늘어났는지 여부를 잘 확인해야 한다. 초 음파에서도, 늘어나 있지 않은 이하선관은 관찰하기 어려운 경우가 많다.

이하선 농양의 치료는 수분을 공급하고 항생제 정맥주사 와 구강위생을 향상시키는 것이다. 고식적으로는 농양의 외 과적 배농술은 이하선 종양 수술과 똑같은 절개방법으로 이 하선 부위의 피판을 박리한 후, 안면신경의 주행과 평행하게 이하선 실질부위에 수평으로 여러 개의 절개를 가하는 것으 로 알려져 있다. ${ }^{3}$ 상기 방법은 안면신경의 손상의 우려나, 수 술 후 상처회복의 지연, 출혈, 피부의 흥터 등의 부작용이 발 생할 수 있다. ${ }^{3)}$ 또한 전신마취가 필요로 하므로, 전신상태가 좋지 않은 환자에서는 시행하기 어려운 점이 있다. 이런 고식 적인 절개 대신에 초음파와 투시장비를 이용한 경피적 배농 술은 전신마취의 필요가 없으며, 초음파와 투시 하에 정확하 게 농양의 중심부에 도관을 유치시킬 수 있다(Fig. 1). 따라 서 쉽고, 환자의 피해를 최소화할 수 있다. 이하선의 심엽에 서 농양이 발생한 2 명의 환자에서도 합병증 없이 치료하였으 며, 농양이 크기가 크지 않은 경우에도 별다른 문제 없이 배 농할 수 있었다. 경피적 배농술 후 처음 배농한 부위 이외에 다른 곳에서 새로운 농양이 발생하였거나, 배농 중에 처음 농양의 위치와 분리되어 남아 있게 되는 경우는 재원기간이 늘어났다. 이때에는 초음파를 보면서 굵은 바늘로 반복 흡인 하여 치료하였거나(2번 환자), 카테타를 새로 위치시키거나, 교체하여 치료하였다(5번 환자). 초음파 유도하 경피적 배농 술은 경부 심부 농양 치료에도 효과가 있다고 국내에서 보고 하였으며, 기도폐색이나 패혈증 등의 시급한 상황이 아니면,
고전적인 수술적 절개 및 배농에 비해 흥터나 창상감염, 수 술의 합병증을 피할 수 있는 장점이 있다고 보고하였다.")

9번 환자의 경우는 고령에 당뇨, 만성신부전, 간경화와 같 은 만성질환과 간암, 대장암의 병력이 있었으며, 처음부터 저 작근 공간과 이하선 심부에 농양이 발생하여 경피적 배농을 두 군데 시행하였음에도, 패혈증으로 급격히 진행하여 사망에 이르게 되었다. 면역억제자나 고령의 환자에서 이하선 농양 은 패혈증으로 급격히 이환될 수 있음을 주의해야 하겠다. ${ }^{2)}$

경피적 배농술은 보통 단일엽에 생긴 농양에 효과적이라 고 알려져 있으나, 여러 공간을 동시에 침범한 경우나 다엽성 으로 발생한 경우, 명백한 경계를 형성하지 않은 농양, 근막 을 타고 퍼지는 괴사성 근막염, 종격동염이 발생한 경우에는 경피적 배농술은 제한적이며, 수술적으로 절개 배농술이 필 요하다. ${ }^{13)}$ 또한, 경피적 배농술이 효과적이기 위해서는 치료 기간 내내 배농관이 농양 중앙에 위치되어야 하는데, 배농관 의 끝이 농양벽에 닿거나, 빠지지 않도록 주의해야 하며, 배 농관의 기능 이상이 의심되면 초음파 등으로 확인해야 한다.

본 연구의 단점으로 대상군이 크지 않으며, 또한 초음파와 투시하 경피적 배농을 시행한 것만을 분석하였기 때문에 외 과적 배농술을 시행한 경우와 비교하여 재원기간, 합병증 등 을 비교할 수 없었다. 추후 다기관 연구 등을 통한 추가 연구 등이 필요할 것으로 보인다.

\section{REFERENCES}

1) Krippaehne WW, Hunt TK, Dunphy JE. Acute suppurative parotitis: a study of 161 cases. Ann Surg 1962;156:251-7.

2) Tan VE, Goh BS. Parotid abscess: a five-year review--clinical presentation, diagnosis and management. J Laryngol Otol 2007;121 (9):872-9.

3) Perzik SL. Surgical management of acute parotitis. Arch Surg 1962; 85:247-51.

4) Han KY, Lee JH, Kim JH, Kim JY, Shim BS, Song YJ. Ultrasonography guided percutaneous aspiration and drainage of 
deep neck abscesses. Korean J Otorhinolaryngol-Head and Neck Surg 2009;52(4):354-8.

5) Lee HS, Park JW, Lee YS, Nam SY. A case of facial nerve paralysis following parotid abscess treated by catheter drainage. Korean J Otorhinolaryngol-Head and Neck Surger 2014;57(6):415-9.

6) Takahashi A, Martini MZ, Seo J, de Oliveira Neto HG, Shinohara EH. Ultrasound-guided needle aspiration of parotid abscess. Indian J Dent Res 2012;23(3):423-5.

7) Ganesh R, Leese T. Parotid abscess in Singapore. Singapore Med J 2005;46(10):553-6.

8) Nusem-Horowitz S, Wolf M, Coret A, Kronenberg J. Acute suppurative parotitis and parotid abscess in children. Int J Pediatr Otorhinolaryngol 1995;32(2):123-7
9) Chatterjee A, Varman M, Quinlan TW. Parotid abscess caused by Mycobacterium tuberculosis. Pediatr Infect Dis J 2001;20(9):912-4.

10) Smith DR, Hartig GK. Complete facial paralysis as a result of parotid abscess. Otolaryngol Head Neck Surg 1997;117(6):S114-7.

11) Kristensen RN, Hahn $\mathrm{CH}$. Facial nerve palsy caused by parotid gland abscess. J Laryngol Otol 2012;126(3):322-4.

12) Work WP. Cysts and congenital lesions of the parotid gland. Otolaryngol Clin North Am 1977;10(2):339-43.

13) Biron VL, Kurien G, Dziegielewski P, Barber B, Seikaly H. Surgical vs ultrasound-guided drainage of deep neck space abscesses: a randomized controlled trial: surgical vs ultrasound drainage. J Otolaryngol Head Neck Surg 2013;42:18. 